\title{
A Critical Discussion of Daniel A. Bell's Political Meritocracy
}

\author{
Huang Yushun 黃玉順 \\ Professor of philosophy, Shandong University, China \\ hyso531@163.com
}

Translated by Kathryn Henderson

\begin{abstract}
"Meritocracy" is among the political phenomena and political orientations found in modern Western democratic systems. Daniel A. Bell, however, imposes it on ancient Confucianism and contemporary China and refers to it in Chinese using loaded terms such as xianneng zhengzhi 賢能政治 and shangxian zhi 尚賢制. Bell's "political meritocracy" not only consists of an anti-democratic political program but also is full of logical contradictions: at times, it is the antithesis of democracy, and, at other times, it is a supplement to democracy; sometimes it resolutely rejects democracy, and sometimes it desperately needs democratic mechanisms as the ultimate guarantee of its legitimacy. Bell's criticism of democracy consists of untenable platitudes, and his defense of "political meritocracy" comprises a series of specious arguments. Ultimately, the main issue with "political meritocracy" is its blatant negation of popular sovereignty as well as the fact that it inherently represents a road leading directly to totalitarianism.
\end{abstract}

\section{Keywords}

Democracy - meritocracy - political meritocracy - totalitarianism

It is rather surprising that, in recent years, Daniel A. Bell's views on "political meritocracy" have been selling well in China. In addition, the Chinese edition of his most recent and representative work, The China Model: Political 
Meritocracy and the Limits of Democracy, ${ }_{1}^{1}$ was translated not long ago using the Chinese title Political Meritocracy: Why Meritocracy Is More Appropriate for the Chinese Context Than Electoral Democracy, ${ }^{2}$ and a large number of readers have been receptive to Bell's ideas. Nonetheless, we find it necessary to offer a critique of the views advanced by Bell, because this "political meritocracy" (also translated as shangxian zhi 尚賢制) ${ }^{3}$ inherently represents a slippery slope that could lead to totalitarianism, which would severely and damagingly affect not only contemporary Confucianism and China in general but also the world's other political civilizations.

\section{The Convoluted Logic of "Political Meritocracy"}

\subsection{The Confusion Surrounding the Concept of "Political Meritocracy"}

It cannot be said for sure whether the conceptual murkiness surrounding Bell's use of the terms "meritocracy" and "political meritocracy," as well as their Chinese translations-namely, xianneng zhengzhi 賢能政治 and shangxian $z h i^{4}$ —is intentional, but it does, ultimately, mislead the reader.

1.1.1 The Original Meaning of Meritocracy as "Elitism"

As is well known, the term "meritocracy" first appeared in the dystopian and satirical novel The Rise of the Meritocracy, written by the British sociologist Michael Young and published in $1958 .{ }^{5}$ As has already been pointed out,

1 Daniel Bell, The China Model: Political Meritocracy and the Limits of Democracy (Princeton: Princeton University Press, 2015).

2 Daniel Bell [Bei Danning 貝淡寧], Xianneng zhengzhi: weishenme shangxianzhi bi xuanju minzhuzhi geng shihe zhongguo 賢能政治: 為什麼尚賢制比選舉民主制更適合中國 [The China Model: Political Meritocracy and the Limits of Democracy], trans. Wu Wanwei (Beijing: citic Publishing Group, 2016).

3 Translator's note: Literally, a system in which people of high merit or virtue are held in high regard.

4 Translator's note: The literal meaning of xianneng zhengzhi 賢能政治 could be "politics in which the virtuous and talented assume a leading role."

5 Michael Young, The Rise of the Meritocracy, 2d rev. ed. (London: Transaction Books, 2004). In fact, before that, Alan Fox had already published an article titled "Class and Equality," in Socialist Commentary, May (1956), in which he discussed the term "meritocracy." However, the Oxford English Dictionary records the first appearance of the term as being in Michael Young's novel. See Jo Littler, “Meritocracy as Plutocracy: The Marketising of 'Equality' under Neoliberalism," New Formations, nos. 80-81 (2013). 
Actually, the translation into Chinese of the term "meritocracy" by the expression renren weixian 任人唯賢6 definitely remains a subject of dispute. After all, "merit" refers, originally, to things that are more of an instrumental nature, such as personal strengths, worth, and achievements, and it doesn't possess at all the moral significance carried by the word xian 賢. ${ }^{7}$ Although the principles behind "meritocracy" as a political philosophy emerged from the rationalism of the seventeenth-century Enlightenment movement, the word itself was coined by the British sociologist and Labour Party politician Michael Young. In his allegorical and satirical novel The Rise of the Meritocracy, the author imagines a world where the hereditary system that currently largely defines the accession to power in England has collapsed and has been replaced by a governing elite that is selected based on its members' intelligence quotient. Members of the working class with excellent educational backgrounds have, as a result, joined the elite, but eventually, the enmity felt by the lower strata toward them exceeds even the dissatisfaction they used to feel toward the aristocrats who dominated politics in the past. This hatred culminates in 2034, when a violent revolt breaks out and ends up overthrowing the ruling elite.

In 2001, Young wrote an article for The Guardian in which he criticizes Tony Blair, who was then serving as prime minister of the United Kingdom and leader of the Labour Party and who promoted, quite unknowingly, the political principle of "meritocracy" as a new catchword. As Young puts it, members of the aristocratic elite that have traditionally governed in Britain are fully aware that they owe their leading position to their bloodline, and they also understand very well the necessity of demonstrating a certain degree of moderation. In contrast, members of the new elite-who have risen to their position by means of their excellent educational achievements - are being self-righteous and blindly believe in the moral legitimacy of their own political position (because they believe they have been relying entirely on their own efforts and achievements). For this reason, they will seek advantages even more unscrupulously, forgetting and betraying the class to which they used to belong. The lower strata are hence left with no one to represent the popular will, and in the

6 Translator's note: The expression translates as "to appoint people merely according to their merit and virtue."

7 Translator's note: The word xian 賢 could be translated as "virtuous." 
course of democratic progress, their voice is gradually less and less heard, a situation that ultimately instills a feeling of alienation in the masses. ${ }^{8}$

For a relatively thorough analysis of "elitism," we strongly recommend reading Jo Littler's article, "Meritocracy as Plutocracy: The Marketising of 'Equality'

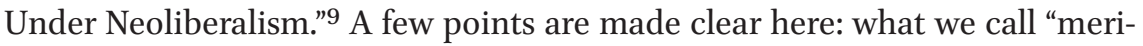
tocracy" should translate into Chinese as "elitism" [jingying zhuyi 精英主義] or as a "system of elitism" [jingying tizhi $i$ 精英體制] and remains purely a Western discourse. Far from being the antithesis of democracy, it is, on the contrary, a political phenomenon that occurs within democracies. Moreover, it is not a universal and intrinsic quality of democratic systems but, rather, a political phenomenon that is currently being seen in some democratic states.

To use the term "meritocracy" to refer to the political reality of "elitism" that has prevailed in democratic societies conveys the same satirical allusion that is present in Michael Young's novel. Wealth and power might not appear to be distributed according to the lineage of one's family background but, instead, according to what we deem to be "merit" (or achievements) (and that must be understood as "IQ + Effort = Merit" $[\mathrm{I}+\mathrm{E}=\mathrm{M}])$. People may seem to have access to equal opportunities; yet, in reality, the family into which one is born and the environment in which one grows up differ from one person to another and have an impact on the conditions and opportunities that allow one to become part of the "elite" - or not. This system thus becomes just another kind of unfair hereditary system. A good example of this is the United States, a democratic country "that prides itself on being a meritocracy."10 This is why the title of Michael Young's article is "Down with Meritocracy."11

Clearly, "meritocracy" remains a concept that pertains to Western modernity. Far from opposing democracy, it is a reassessment of the current state to which democratic systems have evolved, in the hope of redressing the situation. ${ }^{12}$ In fact, we could go so far as to characterize "meritocracy" as nothing more than a contentious arena in which competing political parties in a democratic system debate. The term "meritocratic system" ends up being pejorative

8 Ye Pengfei 葉鵬飛, “Sui you su er bu de shi 雖有粟而不得食 [Although Revenues Are Being Made, People Can't Enjoy Them]," Lianhe zaobao, August 4, 2013, http://www .zaobao.com/forum/views/opinion/story20130804-236753/.

$9 \quad$ Littler, "Meritocracy as Plutocracy."

$10 \quad$ Edward Luce, "The End of American Meritocracy," Financial Times, May 8, 2016, https:// www.ft.com/content/c17d402a-12cf-11e6-839f-2922947098fo/.

11 Michael Young, "Down with Meritocracy," The Guardian, June 29, 2001, http://www .theguardian.com/politics/2001/jun/29/comment/.

Littler, "Meritocracy as Plutocracy." 
because the system itself leads to the emergence of new ideologies or organizational principles that reinforce both power inequalities and the idea of social hierarchy based on class. ${ }^{13}$ It also perfectly encapsulates the corruption that, at the current stage of Western democratic politics, is becoming more apparent. This malpractice is accentuating the decline in social mobility and hardening of class barriers as well as widening the gap between rich and poor, creating a situation that led to the populism now trending in the United States and other parts of the Western world and that is challenging the powers in place. In sum, according to the original meaning of the term, "meritocracy" is neither something from the past nor something that stands in opposition to contemporary democratic systems; on the contrary, it reflects the current stage and conditions to which democratic systems have evolved-conditions that are still waiting to be improved.

Keeping in mind the considerations above, the present article aims to discuss not so much Young's concept of "meritocracy" but, rather, the concept of "political meritocracy" that Bell himself "crafted," as well as its Chinese translations, xianneng zhengzhi and shangxianzhi. ${ }^{14}$

1.1.2

Daniel A. Bell's Concept of "Political Meritocracy"

Daniel A. Bell tries to attach the label of "political meritocracy" to China's current anti-democratic system, by presenting it as a system where power is handed to people of high merit and virtue, accordingly with the direction already set by ancient China's Confucian system. Bell actually succeeds in creating a lot of confusion regarding the concept of "meritocracy" itself, and in order to accomplish this, he first has to "purge" the word "meritocracy" from its pejorative meaning. ${ }^{15} \mathrm{He}$ hence declares: "In English, the word 'meritocracy' still carries quite a lot of negative connotations. This is why I am talking about

13 Ibid.

14 Translator's note: In opposition to the traditional translation of the term as jingying zhengzhi 精英政治 in which jingying 精英 refers to the elite.

15 The reader may refer to Marco Del Corona's interview with Daniel Bell, originally in Italian: Marco Del Corona, "Facciamo l'essame a chi comanda: Daniel Bell e la meritocrazia political," Corriere della sera, May 17, 2015, http://leviedellasia.corriere. it/?r=4\&s=daniel+a.+bell/; translated into Chinese as: Marco Del Corona, "Zai yi ge xifang xuezhe yanzhong, zhongguo moshi meili hezai 在一個西方學者眼中, 中國 模式鬼未何在 [According to a Western Scholar, the China Model Is Full of Promises],” trans. Liu Xushuang 劉旭爽, Guanchazhe, July 21, 2015, http://www.guancha.cn/Bei DanNing/2015_07_21_327510.shtml. 
'political meritocracy' in order to stress the particular ways in which I make use of the term."16

For this reason as well, Bell purposely distinguishes between "political meritocracy" and "economic meritocracy," asserting his intention to limit his discussion to the former. As for "economic meritocracy," it "can refer to a principle governing the distribution of economic resources: [it] is a system that distributes wealth according to ability and effort rather than class or family background."17 It seems to be quite evident that this would serve as an indicator of social progress; however, Bell opposes the idea and cites as evidence to support his point both Karl Marx's criticism of capitalism and John Rawls's condemnation of this system as leading to the emergence of "a callous meritocratic society."18 What Bell advocates, therefore, is not "distribut[ing] wealth according to ability and effort" but, rather, distributing power according to ability and effort. This, precisely, is what Bell means when he uses the term "political meritocracy."

We cannot refrain from asking, however: why should we consider these two types of meritocracy differently? On what grounds is it justified to apply double standards? Moreover, the crux of the matter is this: if we stand by Bell's position regarding political meritocracy—namely, that political power should be distributed according to ability and effort-then, the inevitable outcome of this is that people with abilities that are considered lesser will ultimately find themselves occupying a lower status and will not be considered worthy of enjoying political power. Clearly, this position consists in an anti-democratic and extreme form of elitism, as it divests people of their political power.

The Chinese Rendering of the Term "Political Meritocracy" by Xianneng Zhengzhi or Shangxian Zhi

As indicated above, what Bell calls "meritocracy" has nothing to do with China or with Confucianism but is, in fact, a contemporary political phenomenon that is entirely Western. Yet Bell declares: "Since my book mainly deals with China, it is worth mentioning that in Chinese, we used the word xianneng zhengzhi to talk about what usually translates as jingying zhengzhi (political meritocracy)."19 Regardless of whether he does so intentionally, Bell clearly misleads his readers, and, by forcing a Western invention on China, he

16 Translator's note: This citation appears only in the Chinese translation of Del Corona's interview with Bell, "Zai yi ge xifang xuezhe yanzhong."

17 Bell, The China Model, 4-5.

18 Ibid.

19 Translator's note: This citation appears only in the Chinese translation of the interview by Del Corona, "Zai yi ge xifang xuezhe yanzhong." 
"assaults" China's traditional political culture and, even more so, the Confucian tradition of political philosophy. ${ }^{20}$ Political Democracy

One thing needs to be made clear from the beginning: Bell's "political meritocracy" does not at all involve the sort of meritocratic system that is prevalent in democratic regimes. It actually has nothing to do with the original meaning of the word "meritocracy," since in his view, "meritocratic institutions within an overall democratic context ... can exercise power only in a restricted domain and are ultimately accountable and subordinate to democratically elected politicians; they are meant to supplement, rather than pose alternatives to, electoral democracy."21 Yet what Bell seeks is for these meritocratic institutions to "pose alternatives" - in other words, for this "meritocratic system" to take precedence over the democratic system. For instance, Bell cites the case of the United States as evidence: "in one of the grand ironies of American public opinion, the United States is still the place where the meritocratic faith burns brightest," 22 something that he qualifies, however, as nothing more than "(false) beliefs." ${ }^{23}$ Similarly, when it comes to the model provided by Singapore, he goes on saying that "[p]erhaps it was a mistake to try to build single-party meritocracy on the foundation (or form) of a democratic electoral system."24 In sum, Bell's "political meritocracy" serves as an "alternative to electoral

20 We draw here a strict distinction between what we call the "Confucian tradition" and "traditional Confucianisms." Traditional Confucianisms refer to the various premodern forms of Confucianism, such as Confucianism at its earlier stage, Confucianism during the Han and Tang dynasties or the neo-Confucianism of the Song and Ming dynasties. The period to which each of these belongs, as well as their characteristics, remain entirely different. By contrast, the Confucian tradition refers to the Confucian principles that persist throughout all of these movements. As for the modern interpretation made out of this particular set of principles, it does not, actually, correspond to anything like Bell's political meritocracy [xianneng zhengzhi], but, rather, corresponds to what we term "civic politics" [guomin zhengzhi]. See Huang Yushun 黃玉順, “Lun ruxue de xiandai xing 論 儒學的現代性 [A Discussion of Confucianism's Modernity]," Shehui kexue yanjiu, no. 6 (2016); idem, “Guomin zhengzhi ruxue-rujia zhengzhi zhexue de xiandai zhuanxing 國民 政治儒學——儒家政治哲學的現代轉型 [Confucianism's Civic Politics: The Modern Transformation of Confucian Political Philosophy]," Dongyue luncong, no. 11 (2015).

21 Bell, The China Model, 20.

22 Translator's note: Here, Bell is actually quoting from Christopher Hayes, Twilight of the Elites: America after Meritocracy (New York: Crown, 2012), 62-63. See Bell, The China Model, 39-40.

23 Bell, The China Model, 39-40.

24 Ibid., 35 . 
democracy"25 — in other words, it is not only democracy's antithesis but also the system that should replace it.

However, there is something quite paradoxical here: Bell contradicts himself by asserting very clearly that he endorses democratic politics. In response to people who point out that his book "consists in an attack against democracy," he attempts to defend himself: "It is not at all my intention to undermine democracy, quite the contrary, I strongly support the idea that countries which have implemented systems of electoral democracy proceed with these.... The alternatives to democracy appear, with no exception whatsoever, to be even more disastrous than the electoral system has been." ${ }^{26} \mathrm{He}$ later declares:

I argued that sustainable political meritocracy requires features typical of democratic societies: the rule of law to check corruption and abuses of power, and freedom of speech and political experimentation to prevent the ossification of political hierarchies.... political meritocracies will find it difficult if not impossible to solve the legitimacy problem without giving the people the right to political participation. ${ }^{27}$

He also admits that "it is hard to imagine a modern government today that can be seen as legitimate in the eyes of the people without any form of democracy."28

Hence, Bell is caught in a series of contradictions: on the one hand, he advocates "meritocracy" and opposes democracy; on the other hand, he also sums up the problem as one of "reconcil[ing] political meritocracy and democracy."29 That is how much confusion reigns in Bell's work.

\section{3}

The Absurdity of Bell's Logic

The logic hiding in Bell's views is as follows: that is how Chinese society has traditionally been, and therefore that is how it should remain for the time being and for the future to come. He writes: "In the past, political meritocracy has always been at the core of Chinese political culture, and it will likely remain

25 Ibid., 58; Bell, "Foreword to the Chinese Edition," in Xianneng zhengzhi, xii.

26 Bell, "Foreword to the Chinese Edition," xii. Translator's note: This is a translation of a passage that is found only in the Chinese translation of the book. The reader might also refer to chapter 1, n16 (p. 201), in which Bell writes: "My aim is not to undermine faith in electoral democracy in countries that have implemented such systems, if only because the practical alternatives tend to be military dictatorship or authoritarian populism."

27 Bell, The China Model, 152.

28 Ibid., 151.

29 Ibid., 150. 
as such in the future." ${ }^{30}$ Later, he affirms: "Now that China has progressively been creating and implementing a meritocratic system in order to select and appoint political leaders with outstanding intellectual abilities, social skills and moral character, should we not expect that any sort of improvement ought to rest on these foundations that have already been laid out?"31 If we are to follow this kind of logic, it would also be possible for us to ask: since ancient China progressively saw the formation and implementation of absolute monarchy, should it not mean that any following development ought to rest on these foundations? Because humanity has engaged in slavery, should it not mean that any following development should have rested on such foundations? And if we are to keep on going like this: just because all humans were once primates similar to apes and monkeys, should it not mean that any development ought to proceed from this idea? This kind of logic truly is absurd!

\section{The Main Fallacies at Work in Bell's Political Meritocracy}

\subsection{The Supposed "Four Key Flaws" of Democratic Regimes}

In his book, Bell discusses four main flaws of electoral democracy, which he also describes as four different sorts of "tyrannies."

2.1.1

"The Tyranny of the Majority"

The thing is, Bell himself admits that democratic regimes have already been addressing this problem: "In the twentieth century, however, liberal democracies consolidated constitutional restraints on majority rule, and liberal democracies typically protect minority groups and unpopular individuals from gross abuses of human rights"; 32 "most democracies have protections for minority groups and individuals. The liberal part of democracy is meant to protect the interests of minorities by means of various constitutional mechanisms that restrain majorities from violating the basic rights of people."33

30 Bell, “Cong 'yazhou jiazhiguan' dao 'xianneng zhengzhi' 從‘亞洲價值觀,到‘賢能政治' [From 'Asian Values' to 'Political Meritocracy']," Wen shizhe 文史哲 [Journal of Literature, History and Philosophy], no. 3 (2013).

31 Bell, "Foreword to the Chinese Edition," xiii-xiv.

32 Bell, The China Model, 21.

33 Bell, "Appendix 2: A Conversation between a Communist and a Confucian," in The China Model, 4, available at http://assets.press.princeton.edu/releases/mio418-2.pdf. 


\subsection{2 "The Tyranny of the Minority"}

Here, Bell is actually referring to the "tyranny of the wealthy minority," 34 that is, to the capitalists who control politics. Bell believes that the fundamental reason such a "tyranny" has emerged is the wide gap that still exists between rich and poor, as well as income inequality in general. He recognizes, nonetheless, that the situation is far from better in "meritocratic systems" such as the ones he praises: "China and Singapore are not doing much better than the United States in terms of income inequality, which has worsened over the past two decades"; "the 'tyranny of the minority' may be similarly problematic in China and the United States." 35 At the same time, Bell concurs that "many electoral democracies - such as [his] home country, Canada - do a much better job of limiting the influence of money in politics." 36

\subsection{3 "The Tyranny of the Voting Community"}

By this, Bell means that a nation-state's government's policies apply differently to citizens and noncitizens: "Political equality ends at the boundaries of the political community: those outside are neglected." ${ }^{37}$ He goes on to say: "democratization tends to strengthen the political salience of national identity."38 Nonetheless, common sense tells us that democratization and attempts "to strengthen the political salience of national identity" are not necessarily connected: undemocratic states have similarly aimed at strengthening national identity, and examples of ultranationalist movements brandishing the banner of "patriotism" are ubiquitous. Actually, Bell fails to identify the real heart of the matter: namely, that in this era of nation-states, this is a common problem and will remain so as long as human societies do not find their way out of this era. ${ }^{39}$

\subsection{4 "The Tyranny of Competitive Individualists"}

Everybody who only cares about his own interests and in the vicious competition that reigns in electoral democracies is an individualist, and this results

\footnotetext{
34 Bell, The China Model, 42.

35 Ibid., 43, 46.

$36 \quad$ Ibid., Appendix 2, 9.

37 Ibid., 46.

38 Ibid.

39 See Huang Yushun 黃玉順, “Yishen weiben' yu 'datong zhuyi'- 'jiaguo tianxia' huayu fansi yu 'tianxia zhuyi' guannian pipan '以身為本” 與 ‘大同主義”—“家國天下”話語反思 與 ‘天下主義” 觀念批判 [A Rethinking of the Discourse of the Nation under Heaven and a Critique of the Notion of the Heavenly Doctrine]," Tansuo yu zhengming, no. 1 (2016).
} 
in the destruction of social harmony. ${ }^{40}$ However, this sort of thinking, which draws an opposition between "competition" and "harmony," is not tenable. Bell discerns two levels of social harmony: (1) "Harmony, at a minimum, means peaceful order (or the absence of violence). Conflict is unavoidable, but it should be dealt with in a nonviolent way to establish a peaceful order."41 Can we not, precisely, affirm that electoral democracy consists in a nonviolent way to govern, or that it helps us achieve a peaceful order? Conversely, when societies that are governed by undemocratic regimes attempt to "establish a peaceful order," do they not generally do so by means of violent revolts? (2) The highest level of harmony is one that admits "diversity"and opposes competition. Bell considers this "the Confucian idea of harmony,"42 but this way of looking at things is indeed biased. Confucianism never rejected competition; it has, however, advocated competition that, at the same time, shows respect for both rites and order. As Confucius is known to have said: "The student of virtue has no contentions. If it be said he cannot avoid them, shall this be in archery? But he bows complaisantly to his competitors; thus he ascends the hall, descends, and exacts the forfeit of drinking. In his contention, he is still the junzi In competition, the junzi must act exactly as he would do in the context of the contest taking place during the archery ceremony, which means in a competition that follows a peaceful procedure. Can we not qualify electoral democracy as a peaceful procedure, or should it be described as a violent struggle between parties?

\subsection{The Four Main Premises of Bell's Political Meritocracy}

According to Bell, the establishment of a "political meritocracy" is based on four "assumptions": "( 1 ) it is good for a political community to be governed by high-quality rulers; (2) China's one (ruling) party political system is not about to collapse; (3) the meritocratic aspect of the system is partly good; and (4) it can be improved." 44 Let's limit ourselves here to Bell's first assumption. When Bell talks about "high-quality rulers," he is referring to people with both high morals and abilities. Yet both history and the current reality serve as warnings in this regard. We cannot rely on rulers' morals: a good system might have rulers act in the right manner, but a bad system will allow them to be corrupted.

\footnotetext{
$40 \quad$ Bell, The China Model, 55 .

41 Ibid.

42 Ibid., 43.

43 Analects一Ba yi. 論語・八佮. Yang Bojun 楊伯峻, Lunyu yizhu 論語譯注 [Translation and Commentary on the Analects] (Beijing: Zhonghua Book Company, 2002), 25.

44 Bell, The China Model, 8.
} 
Neither can we rely on rulers' abilities; in a bad system, the stronger the rulers' abilities are, the more harm they are likely to cause.

\subsection{Bell's Counterarguments to the Three Main Problems in Political Meritocracy}

Bell concedes that what he calls "political meritocracy" still has "three key problems." 45

2.3.1. The first problem is corruption, in other words, "rulers ... are likely to abuse their power." 46 Bell's basic point of view in this regard is that "electoral democracy is not always ... a strong bulwark against corruption," that "[w] hat does seem to help combat corruption is the level of economic development," and finally, that "high [gross domestic product] per capita is still the best bulwark against corruption." ${ }^{47} \mathrm{He}$ does not check whether these arguments are in keeping with facts but, rather, examines what causes corruption, the first of which he identifies as the lack of a democratic system: "The most obvious cause of corruption is the absence of independent checks on the power of the government." Despite the fact that present "meritocracies" have adopted all kinds of measures in this regard, he concedes that "[s]till, the basic problem has not changed: there are no independent legal or political institutions with the formal power to investigate or check the power of the collective leadership.... The problem of one bad emperor may have been solved, but not the problem of how to avoid several bad leaders at the top of a rotten system." 48

2.3.2. "Political hierarchies may become frozen and undermine social mobility." ${ }^{\text {"9 }}$ The examples of ossification that have occurred in democratic countries and that Bell identifies, in addition to examples taken from ancient Chinese history, simply do not pertain to the same categories of problems and have an entirely different nature. Moreover, the ossification problems emerging in democratic regimes are not nearly as severe as what happens in the "meritocratic" regimes that Bell admires. For instance, in China, the "secondgeneration" phenomenon, in which the offspring of powerful people inherit their parents' status (as do the children of entrepreneurs [fu erdai 富二代] or officials [guan erdai 官二代]), is getting worse by the day.

\begin{tabular}{ll}
\hline 45 & Ibid., 111. \\
46 & Ibid., 8. \\
47 & Ibid., 112-13. \\
48 & Ibid., 116. \\
49 & Ibid., 8.
\end{tabular}


2.3.3. The problem of legitimacy. Bell admits that "[t]he legitimacy problem is perhaps the most serious threat to the meritocratic system" 50 and that "it is difficult to legitimize the system to those outside the power structure." ${ }^{51} \mathrm{He}$ identifies three things that may give the Chinese regime legitimacy, namely "nationalism, performance legitimacy, and political meritocracy." ${ }^{2}$ First, let us rule out the third source of legitimacy mentioned by Bell; otherwise, we might have to surrender to the sort of absurd logic that would have us declare that "meritocracy's legitimacy comes from meritocracy." To regard "performance" as a source of political legitimacy does not hold water either: the performance of tyrants in the ancient past as well as of contemporary authoritarian or totalitarian regimes could qualify as equally fine or, in some cases, could even be considered excellent. Bell admits that "no ruler is so great that he or she should rule depoliticized masses without accountability. It is hard to imagine a modern government today that can be seen as legitimate in the eyes of the people without any form of democracy." ${ }^{3}$ As for regarding "nationalism" as a source of legitimacy, this could prove even more harmful. We might as well reflect some more on the relationship between nationalism and what happened during World War II, particularly, on the totalitarian form of nationalism advocated by the Nazis.

\section{4 "Political Meritocracy" Represented by the China Model}

Bell's monograph discusses "three models of democratic meritocracy" and advocates the establishment of the third one: a model with a democratic structure at the lower levels and a meritocratic structure at the highest levels. ${ }^{54}$ (1) When it comes to the lower levels of governance, Bell highly praises the democratic elections that China has been attempting to put in place in recent years. Yet, while he admits that some problems remain in local-level democracy, he barely elaborates on them. ${ }^{55}$ (2) As for adopting meritocracy at the highest level of government, Bell declares that "[ $t]$ he advantages of 'actually existing' meritocracy in the CCP are clear," but he concedes that "actually existing meritocracy' is flawed." ${ }^{6}$ According to him, when it comes to China's meritocracy's flaws, two aspects should be considered: "Part of the problem is that China lacks democracy at various levels of government that could help check abuses

\begin{tabular}{ll}
\hline 50 & Ibid., 9. \\
$5^{1}$ & Ibid., 8. \\
$5^{2}$ & Ibid., 139. \\
53 & Ibid., 151. \\
54 & Ibid., 152. \\
55 & Ibid., 169. \\
56 & Ibid., 172-73.
\end{tabular}


of power and provide more opportunities for political expression by marginalized groups. But part of the problem is also that political meritocracy has been insufficiently developed in China." ${ }^{57}$ What the first reason outlined here reveals is that there is actually a demand for more democracy, something that contradicts Bell's main objective, which is to make a case for "meritocracy." However, the second reason laid out by Bell indicates the most vital issue affecting the meritocratic system. This system has no way to truly make it "so that government officials are selected and promoted on the basis of ability and morality rather than political connections, wealth, and family background," especially that "[s]till, defenders of political meritocracy at the top must confront the problem of legitimacy," and this may well make meritocracy "increasingly difficult to sustain" in the future..$^{58}$

Bell's conclusion in this book is the "China model," which he attempts one more time to definite: "Since the model-democracy at the bottom, experimentation in the middle, and meritocracy at the top-is unique to China, we can call it the "China model." 59 This corresponds, in fact, to the model that Bell has already dismissed because of how poorly it performs in practice. Yet Bell considers that this model "is both a reality and an ideal. It is a reality that has characterized China's approach to political reform over the past three decades or so. It is also an ideal that can be used as a standard to evaluate political reform and to suggest areas of possible improvement." ${ }^{60}$ But when it comes to "the reality of political reform,"61 this "China expert" has no clue whatsoever about the relationship between "rules" and "unwritten rules" that define Chinese politics. As for his discussion of the "ideal of political reform," 62 Bell ends up negating to a certain extent some of the things he touched upon when presenting the "real" aspects of the China model. Interestingly, with regard to the aspects of "meritocracy" that have not yet been perfected and still need some improvement, Bell constantly returns to introducing democratic elements and goes so far as to suggest that democratic mechanisms are fundamentally needed, if only to serve as safeguards.

\footnotetext{
57 Ibid., $173-74$.

58 Ibid., 174 .

59 Ibid., 180.

$60 \quad$ Ibid.

61 Ibid., 180-88.

62 Ibid., 188-95.
} 


\subsection{An Undisguised Negation of Popular Sovereignty}

Bell's definition of what he calls "political meritocracy" goes as follows: "everybody should have an equal opportunity to be educated and to contribute to politics, but not everybody will emerge from this process with an equal capacity to make morally informed political judgments. Hence, the task of politics is to identify those with above-average ability and to make them serve the political community." ${ }^{2}$ To put it simply, the fundamental principle of "political meritocracy" is that political power should stem from political ability. Here, the people's "equal opportunity ... to contribute to politics" is in fact cancelled out by a very small and "above-average" minority's "capacity to make morally informed political judgments.” This constitutes a flagrant negation of people's political rights. The key issue here is that "meritocracy" goes against citizens' equal access to political participation. Bell declares in his introduction: "My concern, to repeat, is to defend political meritocracy - the idea that political power should be distributed in accordance with ability and virtue." ${ }^{64}$ This means that political power should not actually originate with the people or the entire body of citizens but, rather, with the political elite, who are supposedly more competent and moral. To put it another way, the degree of legitimacy conferred to those who hold political power does not reside with the people but lies in the hands of the political elite. This clearly demonstrates an outright contempt for popular sovereignty as well as an undisguised negation of the principle.

\subsection{The Instrumental Rationality at Work in Bell's Thinking}

According to Bell, "The idea that a political system should aim to select and promote leaders with superior ability and virtue is central to both Chinese and Western political theory and practice." 65 In other words, regardless of whether we are talking about a democratic system or a "meritocratic" one, the aim should always be to select leaders who would be considered "meritorious." Therefore, political systems are merely tools for us to achieve this goal and are not there to protect certain values. As he puts it, although

\footnotetext{
63 Ibid., 32 .

64 Ibid., 6.

65 Ibid., 2.
} 
some philosophers argue that the rights to vote and run for political office are intrinsically valuable for individuals ... such arguments have been vigorously contested and the leading Anglo-American philosophers from J.S. Mill to John Rawls and Ronald Dworkin tend to defend political equality in the form of one person, one vote on instrumental grounds. ${ }^{66}$

This is a deliberate misinterpretation of the thinking of these philosophers, because contemporary Anglo-American philosophy's mainstream has never based its theories on the sort of instrumental grounds invoked by Bell. Rather, it has done so on the grounds of the values encompassed by what we call "natural rights." In fact, the aim served by a certain political system is not to select those to lead the country. Rather, political systems are there to answer the question of who will constitute the bodies that hold power and preside over the rights of citizens. Therefore, in absolutely no way is democracy merely an instrument; on the contrary, it stands for one value in particular: it guarantees popular sovereignty.

\subsection{Totalitarianism's Dangerous Prospects}

Bell's inclination toward totalitarianism is revealed by his discussion of the sources of political legitimacy. It is Bell's opinion that "meritorious" political leaders must possess three key qualities: intellectual abilities, social skills, and virtue. ${ }^{67}$ Of first importance are intellectual abilities, since they are the most crucial element when it comes to legitimacy. For this reason, Bell cites Max Weber's classification of the kinds of political legitimacy conferred on political leaders, that is, traditional authority (in which people approve of a ruler's authority based on tradition or conventions), charismatic authority (when people endorse a leader because of his or her personal charisma), and rational-legal authority (when rulers are endowed with power following a rational and legal procedure). ${ }^{68}$

Bell's portrayal of charismatic political leaders stands out among the three types for his praise-filled tone. Bell mentions "the qualities of leaders that dominate by charisma, that is, domination by virtue of the devotion of those who obey the purely personal charisma of the leader." ${ }^{99}$ The "meritorious" leaders

\footnotetext{
66 Ibid., $17-18$.

67 Ibid., 68.

68 See ibid., 75-77. See also Max Weber's 1919 lecture, "Politics as Vocation," http://www. doc88.com/p-9923360oog177.html.

69 Bell, The China Model, 75.
} 
he describes are none other than the fearful figures to whom he alludes after having declared that "[p]olitical leaders have power over us." ${ }^{\text {"70 }}$ Moreover, Bell adheres to Weber's definition of "the state as a human community that (successfully) claims the monopoly of the legitimate use of physical force within a given territory,"71 and he goes on to affirm that "[t]he political leader must be prepared to use morally dubious means for good results" and that they will have the determination needed to "make use of the instruments of violence for the sake of less-than-perfect political decisions." ${ }^{2}$

Before the portrait sketched by Bell of this sort of leading figure, one cannot help but think of Hitler. This leads Bell to rapidly attempt to differentiate between the "meritorious" leaders he has been promoting and the charismatic type. He writes: "Weber's account of the charismatic political leader seems more applicable in times of warfare or violent civil strife," and he also adds that "[i]n the context of a modernizing, largely peaceful society characterized by collective leadership such as China, the desired traits of a leader are likely to be different, perhaps closer to the characteristics of what Weber calls the 'civil servant."'73 However, in the following sentences, Bell refutes the distinction he has just made:

In imperial China ..., there was no distinction between civil servants and political leaders: the successful examination candidates were put on the road to be political leaders with the power to decide on matters affecting the lives of millions of people (although they were still supposed to serve, in an ultimate sense, at the behest of the emperor). In contemporary China, the public service examinations ... are also stepping-stones to political power; there are not separate tracks for political officials and civil servants. ${ }^{74}$

It is truly hard to discern, in Bell's writing, whether, in the end, an actual difference, in essence, in the charismatic type of authority he depicts exists between the absolutism of China's ancient past and contemporary totalitarianism.

$\begin{array}{ll}70 & \text { Ibid., 151. } \\ 71 & \text { Ibid., 75. } \\ 72 & \text { Ibid., 76-77. } \\ 73 & \text { Ibid., 77. } \\ 74 & \text { Ibid., 77-78. }\end{array}$


At the beginning of this article, we made reference to the fact that meritocracy, which is usually translated into Chinese as jingying zhuyi and not xianneng zhengzhi or shangxian zhi, is a concept that pertains entirely to contemporary Western democratic systems in place. Yet Bell claims that "China has a long tradition of political meritocracy." ${ }^{75}$ In order to obscure the facts, Bell has us completely "lost in translation." He may think that "meritocracy" or xianneng zhengzhi is part of the Confucian tradition, but this is actually a misrepresentation of Confucian political philosophy.

The Original Meaning Behind the Book of Rites' Mention of

"Choosing Men of Talents, Virtue, and Ability"

When they speak about "virtuous and talented people," the meaning of which is behind the word xianneng, people quite naturally think about The Conveyance of Rites [Liyun 禮運], which is chapter 7 in the Confucian classic the Book of Rites [Liji 禮記], and which mentions people in the distant past "choosing men of talents, virtue, and ability": ${ }^{76}$

I never saw the practice of the Grand course, and the eminent men of the three dynasties; but I have my object (in harmony with theirs). When the Grand course was pursued, a public and common spirit ruled all under the sky; they chose men of talents, virtue, and ability; their words were sincere, and what they cultivated was harmony. Thus men did not love their parents only, nor treat as children only their own sons. A competent provision was secured for the aged till their death, employment for the able-bodied, and the means of growing up to the young. They showed kindness and compassion to widows, orphans, childless men, and those who were disabled by disease, so that they were all sufficiently maintained. Males had their proper work, and females had their homes. (They accumulated) articles (of value), disliking that they should be thrown away upon the ground, but not wishing to keep them for their own gratification. (They laboured) with their strength, disliking that it should not be exerted, but not exerting it (only) with a view to their own

75 Del Corona, "Facciamo l'essame a chi comanda."

76 Bell also discusses, at some point, "the ideal of the 'Great Unity' (datong) described in the Book of Rites. See Bell, The China Model, Appendix 2, 32. Translator's note: James Legge's version of the Book of Rites, which is used here, translates the term datong 大同 as "Grand Union." See James Legge, "The Li Ki," in The Sacred Books of the East, vol. 28 (Oxford: Clarendon Press, 1885). 
advantage. In this way (selfish) schemings were repressed and found no development. Robbers, filchers, and rebellious traitors did not show themselves, and hence the outer doors remained open, and were not shut. This was (the period of) what we call the Grand Union.

Now that the Grand course has fallen into disuse and obscurity, the kingdom is a family inheritance. Everyone loves (above all others) his own parents and cherishes (as) children (only) his own sons. People accumulate articles and exert their strength for their own advantage. Great men imagine it is the rule that their states should descend in their own families. Their object is to make the walls of their cities and suburbs strong and their ditches and moats secure. The rules of propriety and of what is right are regarded as the threads by which they seek to maintain in its correctness the relation between ruler and minister; in its generous regard that between father and son; in its harmony that between elder brother and younger; and in a community of sentiment that between husband and wife; and in accordance with them they frame buildings and measures; lay out the fields and hamlets (for the dwellings of the husbandmen); adjudge the superiority to men of valour and knowledge; and regulate their achievements with a view to their own advantage. Thus it is that (selfish) schemes and enterprises are constantly taking their rise, and recourse is had to arms; and thus it was (also) that Yu, Tang, Wen and Wu, king Cheng, and the duke of Zhou obtained their distinction. Of these six great men everyone was very attentive to the rules of propriety, thus to secure the display of righteousness, the realisation of sincerity, the exhibition of errors, the exemplification of benevolence, and the discussion of courtesy, showing the people all the normal virtues. Any rulers who did not follow this course were driven away by those who possessed power and position, and all regarded them as pests. This is the period of what we call Small Tranquillity. ${ }^{77}$

Three periods are brought up in this excerpt: at the very beginning, there is the period of the "Grand Union," in which the "grand course" [dadao 大道] is being practiced; later, there is the period of "Small Tranquillity" in which lived "the eminent men of the three dynasties"; and finally, there is the period in which Confucius finds himself, that is, a period in which rites and music are no longer rightfully honored and in which the moral standards on which society rested are slowly falling apart. This is a description of things going from bad

77 Liji-Liyun 禮記・禮運. Wang Wenjin 王文錦, Liji yijie 禮記譯解 [Translation and Commentary on the Book of Rites] (Beijing: Zhonghua Book Company, 2001), 287. 
to worse. The period of the "Grand Union" refers in fact to the primitive state of society, and Bell indeed also goes on to say that this "ideal ... sounds more like what Marx would call 'primitive communism."'78 However, this is not at all what Confucius intended to say when he sought to sketch what this "Grand Union" would be like. If he says that he himself has never witnessed "the practice of the Grand course, and the eminent men of the three dynasties," he also declares, "but I have my object (in harmony with theirs)." By saying this, Confucius is asserting an ideal that should serve as a direction for the future. There is a desire to re-establish or, to put it more accurately, to go on building a society that resembles that of the "Small Tranquility" or even of the "Grand Union." However, when it comes to clanship and imperial societies as well as the periods of empire that prevailed from the Qin and Han dynasties onward and that were met by later Confucians, they were absolutely not the political ideal that Confucius had envisioned.

Interestingly, the mention by Confucius, in the Book of Rites, of people "choosing men of talents, virtue, and ability" is not part of the period he described as the "Small Tranquility," during which Yu, Tang, Wen, Wu, king Cheng, and the duke of Zhou lived. Rather, it is part of the period of the "Grand Union" that is yet to come. Clearly, this does not correspond in any way to the supposedly ancient "political meritocracy" to which Bell keeps referring. In the end, when it comes to traditional society in ancient China, whether it is the elitist meritocracy described by Michael Young or the equally elitist political meritocracy discussed by Bell, both basically qualify as sheer fiction.

\subsection{Bell's Outright Distortion of Confucian Thought}

Bell goes so far as to claim that "both Plato and Confucius argued for a form of political meritocracy that effectively excludes the majority from political power." 79 To profess that Confucius would advocate the exclusion of the majority from political power is truly a calumny against Confucius. It probably comes from Bell's misreading of the following statement by Confucius: "When right principles prevail in the kingdom, there will be no discussions among the common people." 80 Some elements here should be taken into consideration that seem to have eluded Bell: first, the "discussions" brought up by Confucius $[Y i$ 議 in the original] refer to "public censure" [feiy $i$ 非議] and not to the right to "discuss political matters" [yizheng 議政]. Hence, the philosopher He Yan 何晏 (190-249) interprets the passage as follows: “The master said: Nowhere

78 Bell, The China Model, Appendix 2, 32.

79 Ibid., 151.

8o Analects一Jishi. 論語・季氏. Yang Bojun, Lunyu yizhu, 174. 
would there be censure." Xing Bing 邢旵 (932-1010), for his part, comments: "Yi signifies 'vilification' or 'derision.' The master said that when right principles prevail in the kingdom, the upper levels of government grant consideration to the voice of the people when making political proclamations and that since such conduct prevails among those in power, the common people have no cause neither for censure nor for calumny" 81 Second, it is assumed in this passage that the absence of censure derives from the ruling class's abiding by the right principles; conversely, if rulers lack principles, the common people are obviously more likely to resort to censure. Third, Xing Bing's comment that "the upper levels of government grant consideration to the voice of the people when making political proclamations" indicates that even when the "right principles prevail," "the voice of the people" is still allowed to be heard and people are still allowed to "discuss political matters." Fourth, what Confucius is saying here is aimed precisely at the political powers in place at that period in time, and it should not be taken as the formulation of a principle of political philosophy for which one would claim universality.

Bell simply does not comprehend the political philosophy inherent in Confucianism, and therefore he is not in a measure to differentiate between the political propositions advocated by Confucianism, which are specifically addressed to conditions during a particular period in history, and the universal and basic tenets of Confucian political philosophy. These tenets pertain, furthermore, to the ethics of the classical Chinese system, that is, to the "the Chinese theory of justice," 82 which holds, from its core theoretical structure, that from benevolence [ren 仁] emerges justice [yi 義] and that from justice emerges rites [ $l i$ 禮]. In other words, the spirit of universal love brings about principles of justice, which in turn brings about institutions and norms. According to the basic tenets of Confucian political philosophy, what today's modern way of living requires is precisely the establishment of a democratic system, and not the "meritocratic system" that ends up challenging it.

81 Shisanjing zhushu一Jishi. 十三經注疏・季氏. Xing Bing 邢旵, annot., Lunyu zhushu 論語注疏 [Commentary on the Analects], in Shisanjing zhushu 十三經注疏 (Shanghai: Shanghai guji chubanshe, 1997), 2522.

82 See Huang Yushun 黃玉順, Zhongguo zhengyilun de chongjian-rujia zhidu lunlixue de dangdai chanshi 中國正義論的重建一一儒家制度倫理學的當代闡釋 [The ReEstablishment of the Chinese Theory of Justice: A Contemporary Interpretation of Confucian Ethics] (Hefei: Anhui People's Publishing House, 2013); published in English as: Voice from the East: The Chinese Theory of Justice, trans. Hou Pingping and Wang Keyou (Reading, UK: Paths International, 2016); Huang Yushun 黃玉順, Zhongguo zhengyilun de xingchengZhou Kong Meng Xun de zhidu lunlixue chuantong 中國正義論的形成一一周孔孟荀 的制度倫理學傳統 [The Formation of a Chinese Theory of Justice: The Ethical Tradition from the Duke of Zhou to Confucius, Mencius and Xun Zi] (Taipei: Eastern Publishing, 2015). 
Therefore, the contemporary version of New Confucianism has nothing other than a demand for political democracy. In short, the "political meritocracy" that Bell forces upon Chinese Confucianism is inherently an antidemocratic political program and a road that leads directly to totalitarianism.

\section{Works Cited}

Bell, Daniel [Bei Danning 貝淡寧]. “Cong 'yazhou jiazhiguan' dao 'xianneng zhengzhi' 從 ‘亞洲價值觀' 到 ‘賢能政治' [From 'Asian Values' to 'Political Meritocracy'].” Wen shi zhe 文史哲 [Journal of Literature, History and Philosophy], no. 3 (2013): 5-11.

Bell, Daniel. The China Model: Political Meritocracy and the Limits of Democracy. Princeton: Princeton University Press, 2015.

Bell, Daniel. Xianneng zhengzhi: weishenme shangxianzhi bi xuanju minzhuzhi geng shihe Zhongguo 賢能政治: 為什麼尚賢制比選舉民主制更適合中國 [The China Model:Political Meritocracy and the Limits of Democracy]. Translated by Wu Wanwei. Beijing: crтic Publishing Group, 2016.

Del Corona, Marco. "Facciamo l'essame a chi comanda: Daniel A. Bell e la meritocrazia politica." Corriere della sera, May 17, 2015. http://leviedellasia.corriere .it $/ ? \mathrm{r}=4 \& \mathrm{~s}=$ daniel $+\mathrm{a}$.+bell/.

Del Corona, Marco. "Zai yi ge xifang xuezhe yanzhong, zhongguo moshi meili hezai 在一個西方學者眼中, 中國模式魅力何在 [According to a Western Scholar, the China Model Is Full of Promises].” Translated by Liu Xushuang 劉旭爽. Guancha zhe, July 21, 2015. http://www.guancha.cn/BeiDanNing/2015_07_21_327510.shtml.

Fox, Alan. "Class and Equality." In Socialist Commentary, May (1956): 11-13.

Huang Yushun 黄玉順. "Guomin zhengzhi ruxue-rujia zhengzhi zhexue de xiandai zhuanxing 國民政治儒學一儒家政治哲學的現代轉型 [Confucianism's Civic Politics: The Modern Transformation of Confucian Political Philosophy]," Dongyue luncong, no. 11 (2015): 33-41.

Huang Yushun. "Lun ruxue de xiandai xing 論儒學的現代性 [A Discussion of Confucianism's Modernity]." Shehui kexue yanjiu, no. 6 (2016): 125-135.

Huang Yushun. 'Yishen weiben' yu 'datong zhuyi'- 'jiaguo tianxia' huayu fansi yu 'tianxia zhuyi' guannian pipan '以身為本”與 ‘同主義”- 家國天下”話語反思與 ‘ 天下主義” 觀念批判 [A Rethinking of the Discourse of the Nation under Heaven and a Critique of the Notion of the Heavenly Doctrine]." Tansuo yu zhengming, no. 1 (2016), 30-35.

Huang Yushun. Zhongguo zhengyilun de chongjian-rujia zhidu lunlixue de dangdai chanshi 中國正義論的重建一儒家制度倫理學的當代闡釋 [The Re-Establishment of the Chinese Theory of Justice: A Contemporary Interpretation of Confucian Ethics]. Hefei: Anhui People's Publishing House, 2013. Translated into English as Voice from 
the East: The Chinese Theory ofJustice. Translated by Hou Pingping and Wang Keyou. Reading, UK: Paths International, 2016.

Huang Yushun. Zhongguo zhengyilun de xingcheng - Zhou Kong Meng Xun de zhidu lunlixue chuantong 中國正義論的形成一周孔孟荀的制度倫理學傳統 [The Formation of a Chinese Theory of Justice: The Ethical Tradition from the Duke of Zhou to Confucius, Mencius and Xun Zi]. Taipei: Eastern Publishing, 2015.

Legge, James. The Analects of Confucius. In The Chinese Classics, vol. 1. Taipei: SMC, 2001.

Legge, James. "The Li Ki." In The Sacred Books of the East, vol. 28. Oxford: Clarendon Press, 1885 .

Littler, Jo. "Meritocracy as Plutocracy: The Marketising of 'Equality' under Neoliberalism." New Formations, nos. 80-81 (2013): 52-72.

Luce, Edward. "The End of American Meritocracy." Financial Times, May 8, 2016. https://www.ft.com/content/c17d402a-12cf-11e6-839f-2922947098fo.

Shanghai guji chubanshe 上海古籍出版社. Shisanjing zhushu 十三經注疏. Shanghai: Shanghai guji chubanshe, 1997 .

Wang Wenjin 王文錦. Liji yijie 禮記譯解 [Translation and Commentary on the Book of Rites]. Beijing: Zhonghua Book Company, 2001.

Weber, Max. "Politics as Vocation (1919)." Translator unknown. http://anthropos-lab .net/wp/wp-content/uploads/2011/12/Weber-Politics-as-a-Vocation.pdf.

Yang Bojun 楊伯峻. Lunyu yizhu 論語譯注 [Translation and Commentary on the Analects]. Beijing: Zhonghua Book Company, 2002.

Ye Pengfei 葉鵬飛. “Sui you su er bude shi 雖有粟而不得食 [Although Revenues Are Being Made, People Can't Enjoy Them].” Lianhe zaobao, August 4, 2013. http://www .zaobao.com/forum/views/opinion/story20130804-236753/.

Young, Michael. "Down with Meritocracy." The Guardian, June 29, 2001. http://www .theguardian.com/politics/2001/jun/29/comment/.

Young, Michael. The Rise of the Meritocracy ( $2 \mathrm{~d}$ rev. ed.). London: Transaction Books, 2004. 